Check for updates

Brooklyn, NY

writingblock@protonmail.com

Cite this as: BMJ2021;373:n1397

http://dx.doi.org/10.1136/bmj.n1397

Published: 2 June 2021

COVID-19 VACCINES

\title{
US college covid-19 vaccine mandates don't consider immunity or pregnancy, and may run foul of the law
}

\section{The requirement for vaccination with products under emergency use authorisation is new legal territory, finds Jennifer Block}

\section{Jennifer Block freelance journalist}

For Joshua Hauser, a junior at the University of California Berkeley, the requirement to get a covid-19 vaccine before fall semester is like getting a plum campus housing assignment. "People are really excited about getting the vaccine on campus," he says. "It will help us feel safe at school." And he's hopeful it will mean a return to normal. "On Zoom, that's all we talk about-we just wish we were together in person."

Beginning in late March, some US colleges and universities began issuing requirements for students to be fully vaccinated against covid-19 if they want to return to campus this autumn. Some policies include faculty and staff. What began as a handful of colleges soon turned into dozens by mid April, and to date, some 350 institutions ${ }^{1}$ have issued such policies-even though all three covid-19 vaccines available in the US remain under emergency use authorisation (EUA) status, and not approved. ${ }^{2}$

Broad mandates in the civilian population of an unapproved product are unprecedented, and the legality may ultimately be answered in court. So at some institutions, the mandates come with fine print. The University of California System policy, for example, is marked DRAFT in red $^{3}$ and will go into effect ${ }^{4}$ only if a vaccine receives full approval.

Other institutions are using the word "approval” more loosely, leaving room for ambiguity. In its 25 March announcement, ${ }^{5}$ Rutgers, a public university in New Jersey, refers to "three vaccines currently approved in the United States.” The University of Massachusetts Lowell initially stated ${ }^{6}$ that a mandate would not be legal, then flipped to issue a requirement for students. In an email to The $B M J$, the university clarified that "students do not need to get a covid-19 vaccination immediately, they simply need to be fully vaccinated with a US approved covid-19 vaccine before returning to campus in the fall."

What if approval is granted the day before classes resume? If University of California students wait, they may find themselves excluded: "If the proposed policy is adopted as drafted, students who choose not to be immunised [and don't qualify for an exemption] ... will be limited in course registration, will not be permitted to attend in-person classes or events, and will not be able to access campus facilities including housing," UC stated in an email response to The BMJ.
At least one school offers an exemption for students who decline covid-19 vaccination specifically because of EUA status. "Based on legal review we felt that was important due to the ambiguity in the federal statute [law]," says Justin Sloan, vice president for institutional effectiveness at St Edward's University in Austin, Texas.

Colleges may require immunisation records for measles and meningitis, but requiring a product under emergency use authorisation would, on the face of it, seem contrary to the law. The Federal Food, Drug, and Cosmetic Act, which authorises the Food and Drug Administration to issue EUA, requires that the recipient has "the option to accept or refuse administration of the product.”

\section{Origins and legality}

No case law addresses EUA vaccines specifically (two cases $^{7}$ are under way), and conflicting interpretations abound. The American Council on Education, representing 1700 institutions, issued a brief ${ }^{8}$ in March predicting that its members' right to mandate "seems likely to be upheld." But Peter Meyers, professor of law emeritus at George Washington University who directed its vaccine injury litigation clinic, told The BMJ that "much more likely than not what they're doing is illegal." The language in the product fact sheets ${ }^{9}$ provided by the Food and Drug Administration (FDA) reflects the law, stating: "It is your choice to receive the

[Pfizer-BioNTech/Moderna/Janssen] covid-19 vaccine.”

It's not clear how many institutions will bend if pressed on this point. An advocacy group has sent legal notices to Rutgers ${ }^{10}$ and Princeton arguing that a mandate "violates federal law, international laws, civil and individual rights, and public policy."

In the Harvard Law Review Blog, ${ }^{11}$ however, Dorit Rubinstein Reiss, a professor of law at the UC Hastings College of the Law, and I Glenn Cohen, a professor of law and deputy dean at Harvard, suggest that federal statute "does not appear to limit what conditions can be imposed on those who refuse a vaccine under an EUA." So a university could, in their view, exclude an unvaccinated student from campus. Brown University, one of the first to issue a policy, instructs that students who refuse and don't qualify for an exemption "will not be permitted to access campus and will need to either petition to study 
remotely from their permanent residence or take a leave of absence.”

Roughly two thirds of the college mandates followed a 29 April recommendation ${ }^{11}$ from the American College Health Association (ACHA) that higher education institutions require covid-19 vaccination. Gerri Taylor, co-chair of the Covid-19 Task Force, which wrote the recommendation, called the issue of legality "moot." "Lawyers from 350 schools now have given their input." But the directive also pointed to "indications that the EUA designation may convert to full FDA approval soon." "We still anticipate it will happen this summer," says Taylor.

The task force is a voluntary group of 26 college health administrators and public health experts that has been meeting since February 2020. "I don't think I would say that we had inside knowledge from the Centers for Disease Control and Prevention (CDC) or FDA on this issue," says Michael Huey, interim CEO of ACHA and member of the Covid-19 Task Force, "But we are in cooperative agreements with CDC about vaccine confidence and acceptance and about building a community of best practice." $\mathrm{He}$ added that the organisation meets people at CDC on a weekly, sometimes daily, basis.

This year, ACHA was granted nearly \$2.5 million (£1.77 million, $€ 2.06$ million) in funding from the CDC to encourage covid-19 vaccine confidence ${ }^{12}$ and acceptance. ${ }^{13}$ It also received $\$ 120$ ooo from Pfizer ${ }^{14}$ in January 2020 to survey colleges on vaccine coverage. The 29 April statement "bubbled up" from discussions at ACHA's Covid-19 Task Force, says Taylor. The task force is separate from the CDC funded initiatives, though there's "a little bit of overlap," with some members also participating in the vaccine acceptance and confidence groups. "It's a statement from us, it's not a statement from CDC,” says Huey.

\section{What about immunity from prior infection?}

The ACHA directive, like most college policies, elides the issue of immunity from a previous SARS-CoV-2 infection. "It's because we're still waiting for CDC to tell us what those antibody levels are," says Huey. "We know the answer to that with diseases like varicella and measles, and we know that people who've had a natural infection with covid-19 and have recovered have immunity. What we don't know is how long that immunity lasts.”

But the same critique also applies to vaccines. Monica Gandhi, an infectious disease specialist at UC San Francisco who is writing and tweeting frequently on the topic, says it would "not be reasonable" for the CDC to set an antibody threshold. "It's much more complex than that." Furthermore, studies comparing the reinfection rate of those who had a covid-19 infection and those who have been vaccinated suggest that they "seem to be equivalent," she says. "No one knows the duration of immunity from natural infection or vaccination, but all the evidence points that both will be long."

Gandhi cites a recent study led by Jennifer Dan, published in Science, ${ }^{15}$ which analysed memory B cells (which produce neutralising antibodies) in individuals eight months post infection and found lasting durability. A multicentre study ${ }^{16}$ published in the Lancet in April reported that those who had covid-19 were 90\% protected against reinfection, and on 10 May, a World Health Organization scientific brief ${ }^{17}$ concluded that "most individuals" will develop strong protective immune responses from a SARS-CoV-2 infection.

For Tracy Beth Høeg, a physician researcher at UC Davis in California who has been publishing about covid-19 and community risk, acquired immunity is "the piece of the puzzle we're missing." "I think a lot of people are waiting for better evidence, but I really think this is something that the CDC and WHO should create guidance for, because we should not ignore natural immunity. We really haven't done that for other diseases." Gandhi echoes that sentiment: "It causes distrust."

It may be worth noting that a decade ago, during another pandemic emergency, the CDC released guidance ${ }^{18}$ stating those who had a confirmed case of H1N1 influenza "should have some immunity" and may elect not to get vaccinated.

Høeg and Gandhi coauthored an essay in The Atlantic (and took heat for it) making the ethical argument that the world should prioritise vaccinating at-risk adults outside of the US before turning to children. She says the same ethics apply to people with prior immunity: "We only have so many vaccines for the entire world," she says. "I struggle when I see young people who are otherwise healthy who've already been infected and then they get two shots of mRNA vaccines-I can't help but think, well, that was probably a waste."

\section{A risk-benefit calculation?}

The ACHA and most college policies also don't address whether pregnant or breastfeeding students will be granted exemptions. The University System of Maryland responded to The BMJ that "pregnancy alone would not provide a basis for an exemption.” The American College of Obstetricians and Gynecologists recently stated that while pregnant people should have access, those "who decline vaccination should be supported in their decision."

In spite of case rates steadily decreasing in the US and widespread availability and effectiveness of the vaccines, college administrators point to the importance of protecting their own communities as well as the larger, off-campus communities, and "no single preventive action or mitigation factor has as much impact" as vaccination, says Sloan of St Edward's. Høeg points out that adults aged $20-49^{19}$ have been responsible for the bulk of community spread, and the return of students to college campuses has been associated ${ }^{20}$ with community outbreaks, such as in Wisconsin ${ }^{21}$ last autumn. But she says the problem with mandates, rather than incentives, ${ }^{22}$ is that "there's the potential for backlash."

Regardless of how the policies are received, universities need not worry about being held liable if, say, a student has a severe adverse reaction to a covid-19 vaccine they thought was required. According to the statute, says Meyers, they "cannot sue anybody. They can only file a claim for compensation.” That adds another wrinkle: covid-19 vaccines are not covered by the national vaccine injury compensation programme, so claims must be made to a less responsive and developed programme ${ }^{23}$ set up for emergencies. According to records Meyers obtained through a freedom of information request, that programme has settled only 29 out of 400 claims since 2005 .

Even if the legality is questionable, institutions of higher education face limited risk in issuing mandates or de facto mandates. And if the language is murky about when the policy goes into effect, says Meyers, "it’s probably not accidental."

I have read and understood TheBMJ policy on declaration of interests and have no relevant interests to declare.

Provenance and peer review: commissioned, not externally peer reviewed.

What Colleges Require the COVID-19 Vaccine? 2021. https://www.bestcolleges.com/blog/list-of colleges-that-require-covid-19-vaccine/

Doshi P.Covid-19 vaccines: In the rush for regulatory approval, do we need more data?BMJ 2021;373:n1244. 
3 https://universityofcalifornia.edu/sites/default/files/review-draft-sars-cov-2-vaccination-programparticipation-policy-04212021.pdf

4 University of California. [DRAFT] Policy: SARS-CoV-2 (COVID-19) Vaccination Program. 2021. https://ucnet.universityofcalifornia.edu/news/2021/04/uc-encourages-covid-19-vaccinations-foruniversity-communities-while-reviewing-policy-requirements.htm

5 Rutgers. COVID-19 update. 2021. https://www.rutgers.edu/news/rutgers-require-covid-19-vaccinestudents

6 UMass Lowell. Updated COVID-19 vaccine guidance at UMass Lowell. 2021. http://web.archive.org/web/20210419021916/https://www.uml.edu/alert/coronavirus/3-9-21vaccine-update.aspx

7 Cathey L. As debate swirls, colleges weigh whether to mandate COVID-19 vaccines. ABC News 2021. https://abcnews.go.com/US/debate-swirls-colleges-weigh-mandate-covid-19-vaccines/story?id $=77326765$

8 American Council on Education. Requiring (or urging) covid-19 vaccinations at colleges and universities for fall 2021. 2021 https://www.acenet.edu/Documents/Issue-Brief-COVID-VaccinesMarch-2021.pdf

9 US Food and Drug Administration. Fact sheet for recipients and caregivers: Emergency use authorization (EUA) of the Moderna covid-19 vaccine to prevent coronavirus disease 2019 (covid-19) in individuals 18 years of age and older. 2021. https://www.fda.gov/media/144638/download

10 Zahneis M. Anti-vaccine group challenges Rutgers U's covid-19 vaccination requirement. The Chronicle of Higher Education 2021. https://www. chronicle.com/blogs/live-coronavirus-updates/anti-vaccine-group-challenges-rutgers-u-s-covid-19-vaccination-requirement

11 Glen Cohen I, Rubinstein Reiss D. Can colleges and universities require student covid-19 vaccination? Harvard Law Review Blog 2021 https://blog.harvardlawreview.org/can-collegesand-universities-require-student-covid-19-vaccination/

12 American College Health Association. ACHA awarded \$2m from CDC to promote covid-19 vaccine confidence. 2021. https://www.acha.org/ACHA/About/ACHA_News/COVID_Vaccine_lnitiative.aspx

13 American College Health Association. ACHA awarded \$450K from CDC to use behavior change to reduce SARS-CoV-2 on college campuses 2021.

https://www.acha.org/ACHA/About/ACHA_News/HECCOP_Initiative.aspx

14 American College Health Association. ACHF partner resources. 2021. https://www.acha.org/ACHA/Foundation/Partner_Resources/ACHA/Foundation/Partner_Resources.aspx

15 Dan JM, Mateus J, Kato Y, etallmmunological memory to SARS-CoV-2 assessed for up to 8 months after infection. Science 2021;371:eabf4063.

16 Hall V], Foulkes S, Charlett A, etalSIREN Study Group. SARS-CoV-2 infection rates of antibody-positive compared with antibody-negative health-care workers in England: a large, multicentre, prospective cohort study (SIREN). Lancet 2021;397:1459-69.

17 World Health Organization. COVID-19 natural immunity: scientific brief, 10 May 2021. 2021. COVID-19 natural immunity: scientific brief, 10 May 2021 (who.int)

18 Centers for Disease Control and Prevention. H1N1 Flu. https://www.cdc.gov/h1n1flu/vaccination/public/vaccination_qa_pub.htm

19 Monod M, Blenkinsop A, Xi X, etal. Imperial College COVID-19 Response Team. Age groups that sustain resurging COVID-19 epidemics in the United States.Science 2021;371:eabe8372.

20 Burke L. Are colleges superspreaders? Inside Higher Ed. 2021. https://www.insidehighered.com/news/2021/01/13/college-openings-led-increase-community-cases-research-says

21 Centers for Disease Control and Prevention. Pray IW, Kocharian A, Mason J. Trends in outbreak-associated cases of covid-19-Wisconsin. MMWR2020;202:114-7.

22 Diep F. These colleges won't mandate a covid-19 vaccine. Instead, they'll try to entice. The Chronicle of Higher Education 2021. https://www.chronicle.com/article/these-colleges-wontmandate-the-vaccine-instead-theyll-try-to-entice

23 Health Resources and Services Administration. Countermeasures injury compensation program (CICP) 2021. https://www.hrsa.gov/cicp/ 